\title{
FREUDIAN TRIPARTITE ON DETECTIVE FICTION: THE TOKYO ZODIAC MURDERS
}

\author{
Dina Amelia, Jepri Daud \\ Universitas Teknokrat Indonesia (UTI), Bandar Lampung, Indonesia \\ E-mail: amelia.dina@teknokrat.ac.Id, Jeprld4ud@gmail.com
}

Received: 11 November 2020

Accepted: 05 December 2020

\begin{abstract}
Sigmund Freud's theory of psychoanalysis developed in the 1940s as mentioned in Barry (2002) was applied to unravel the unconscious psyche of a fictional character in the novel Tokyo Zodiac Murders by Soji Shimada. Tokiko, the villain in the story has been experiencing abusive treatment from her father, stepmother, and stepsisters. The traumas she has received during her life has led to her decision to commit a well-prepared murder that could not be solved for decades. The qualitative method helps to identify and elaborate every component of the unconscious psyche of the villain, especially the Id, Ego, and Super-Ego in the story. The findings show that Tokiko's Ego keeps her alive and survive to plan revenge on her family. Meanwhile, her Super-Ego fails to restrain herself from feeding her desire to conduct the vicious murder. Therefore, Tokiko's Id is responsible for her action which is triggered by her devastating experiences. Her character remains committed and faithful to herself.
\end{abstract}

Keywords: detective fiction, Freudian tripartite psychoanalysis, Tokyo zodiac murder.

\section{Introduction}

Shakespeare once states that truth will come to light: murder cannot be hidden long. A detective is to reveal the truth that is hidden in criminal cases and often pictured as the protagonist character or the hero of the story. Detective is well known not only as a law enforcement term but also as a fictional term. The word refers to different kinds of crime stoppers who enforce criminal law as the police's partner (Shpayer, 2011). Detective Fiction first emerged in the nineteenth century and its center of the story is solving the mystery in crime from a close circle of a suspect. The suspect has motives, means, and also the opportunity to conduct a crime (Downing, 2007). The villain in detective stories is portrayed variously from low-class to well-educated upper-class. The readers of detective fiction can have different perceptions toward a villain character in a story depends on their environment, experience, principles, and so forth. In other words, each villain in detective fiction is the manifestation or symbol that emerges from the background of the author or the reader. The term villain is bias and changeable; therefore, it is not adequate to categorize a character without taking any consideration about what the author had in mind. The situation, the social and cultural condition as well as the beliefs may also influence the author in creating a certain character (Blakeney, 2010). Villains in detective fiction possess three traditional motives which are jealousy, revenge, and profit. Yet, some villains are portrayed differently from the others. Their actions are influenced and urged by the unwanted life experiences and hidden desires which are unconsciously kept in the 
unconscious psyche of the character. Villain develops its psychological patterns and conditions as a result of plot development (Downing, 2009). Freudian Tripartite is the tool to disclose the psychological patterns and conditions which influence the villain's actions and decisions.

The tripartite consists of an Id Ego, and Super-Ego or famously known as the psychoanalysis. Sigmund Freud introduces psychoanalysis in the early $20^{\text {th }}$ century to cure his patients who suffered from certain mental illnesses. However, this is also a familiar technique to use in scrutinizing a literary work. Freud in Sarijaloo \& Kiaei states that Id is the basic instinct to fulfill human desires and needs. The Ego can recall some memories in the past and can also play as a mask to be worn to be accepted by society. The last on the list of tripartite is the Super-Ego or the sensor. It plays a role to remind humans to stay in the "line". Super-Ego develops its senses based on the influence of the norms, traditions, religious beliefs that have been optimized throughout one's life (2015). Detective fiction and Freudian tripartite have established their connection ever since detective fiction is known to the public. Agatha Christie, an English writer, who wrote the "whodunnit" stories from the early 1920s, is said to be influenced by the Freudian tripartite. Far from the English society, a Japanese writer, Soji Shimada, also writes detective fiction regarding a story of a disturbed young woman who has been emotionally tortured by her family. The Tokyo Zodiac Murders provides insights into the life of a murderer and the story circles around the murders of the Umezawa family. The case remains a mystery until it is revealed that Tokiko Umezawa, the daughter of Heikichi, is the one who is responsible for the murders. Throughout the story Tokiko does not appear to have an appealing personality; however, Tokiko has been bullied by her family. She has unwanted experiences or traumas which are stored in her unconsciousness and triggers her actions and decisions. The aim of the Freudian tripartite is to reveal her unconscious psyche which is seen from her Id, Ego, Super-Ego which leads to her murdering her whole family.

\section{Literature Review}

The relation between Freudian tripartite and detective fiction has been conducted since the Golden Age of detective fiction between the 1920s and 1930s. Such in Sherlock Holme's novel $A$ Study in Scarlet, the Freudian tripartite reveals the main character's characteristics which include egocentric, destructive, and perfectionist. Holmes' Id is described whenever he is not in the mood, he will seek to fulfill his needs by consuming drugs as an example of his unconscious mind when looking for pleasure. Watson as his close friend and roommate is the only person Sherlock is being nice to. It is an example of his Ego working on his mind trying to adapt to his surrounding, although initially, he is a cold and ignorant person. His Super-Ego is the one that is responsible for his awareness of the clues and to set aside personal feelings. The Super-Ego keeps his sane and eventually helps him to solve the murder (Mario, 2013). Clyde, in the novel An American Tragedy, has a tragic life. The Freudian tripartite assists to disclose the character's personality and provides a much better understanding depiction of a person who cannot resist the temptations to pursue his dreams. There is a constant struggle that happens between Clyde's Id and his Super-Ego. Clyde plans to murder someone named Roberta because she becomes an obstacle to his relationship with Sondra. He has to go through a series of torturing nightmares whenever he thinks about it. Clyde's Id is also responsible for his uncontrolled sexual desire. Meanwhile, the Ego follows the fundamental rules of reality. It bridges Id and Super-Ego. In the darkest moment of his sister's romance, Clyde thinks about how she can survive. Furthermore, he 
also suffers from a guilty feeling when he cannot help his mother. His Super-Ego helps him to re-evaluate and regret his action (Zhu and Bao, 2012). Unlike other villains in the previous detective stories, Shimada's villain is presented as a brilliant yet complex character, not only that she is a woman, but she is a Japanese woman who lives in the 1930s. It is the time when Japanese women are considered less intellectual than men due to their sex.

\section{Research Method}

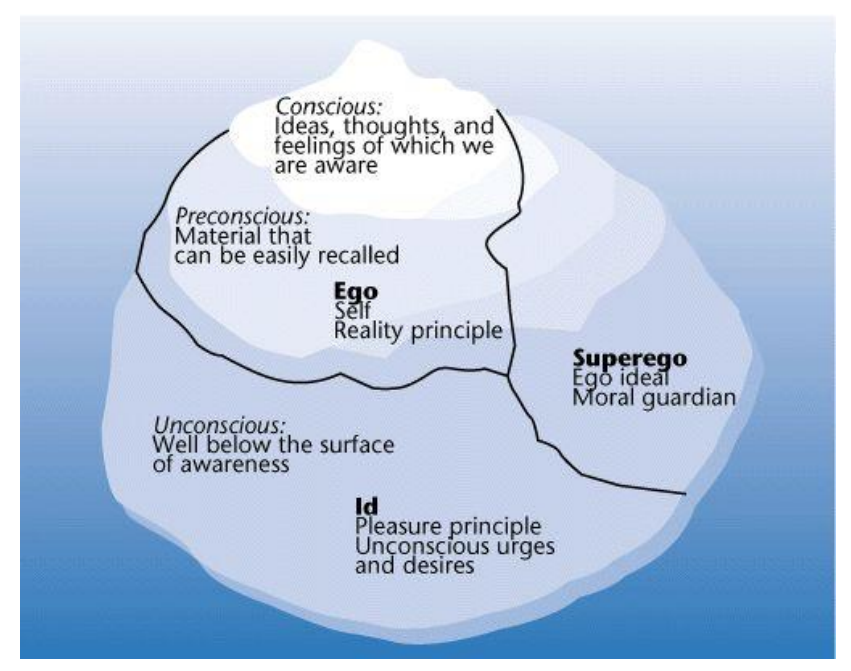

Picture 1. The Mental Iceberg.

The qualitative method is used to identify and elaborate the Id, Ego, and Super-Ego of the villain in the story. The method scrutinizes the contents of the story. It involves the analysis of each component in the story including the title, narration, topic, literature review, theoretical framework, and discussion part (Onwuegbuzie, 2012). Shimada never mentions that the villain in his novel suffers from any psychological condition, but the main character does experience extensive trauma. For that reason, the qualitative method and the Freudian Tripartite as a part of psychoanalysis are sufficient to disclose the unconscious psyche of the villain in the story. The Freudian tripartite, as mentioned in Pope (2002) focuses on the division of the human psyche into three parts: Id is the unconscious part of our psyche. It functions as a storage to store one's repressed memories, desires, trauma, and anxiety. It is the basic instinct to fulfill all human desires and needs and at some points, it also concerns the avoidance of the tense and unpleasant condition. The Ego, on the other hand, is the conscious part to store knowledge, and childhood memories. The existence of an Ego assists a person to fulfill his or her desire without ignoring reality. In other words, the Ego is our actions and behaviors which influence our real life. Furthermore, Freud mentions in Giordano (2020) that the Ego acknowledges reality and the one that can make a clear decision and assists humans to adapt to their surroundings. Ego also helps humans to gain what they have always been desire without ignoring the fact that they are living among others. Therefore, they have to be aware of others' needs. Meanwhile, Super-Ego is the bridge between the Id and the Ego. It is one's internal voice that stops him from doing the wrong thing. The Super-Ego is influenced by the faith, belief, religions, norms, and values in the society where one lives in. It functions as a protection to avoid guilty feelings and regrets. The Super-Ego works as the filter to our actions and thoughts. Furthermore, the Super-Ego is also known as one's "filter" to act based on the law. The Super-Ego constantly 
tells the right from the wrong and it works as an internal voice to trigger guilty feelings before and after doing something wrong (Barry, 2002).

\section{Results and Discussion}

Tokiko is born in the Umezawa family, her father, Heikichi Umeza. At her young age, she has to face the divorce of her father and her mother. As much as she loves her father, she also hates him for mistreating and leaving her mother in suffering due to his affair with another woman, Masako. Her father marries Masako and has a daughter named Yukiko. Masako moves with her three daughters from her first marriage. They are Kazue, Tomoko, and Akiko. Freudian psychoanalysis emphasizes that eventually, the repressed memory will return. Freudian psychoanalysis centers its attention on the unconscious motives and feelings. The Umezawa family treats Tokiko badly as she mentions in her last letter to detective Mitarai.

"Soon after Tae left the Umezawa house, Heikichi married Masako. She was a devil. It may not be fair to speak ill of the dead, but Masako treated me with great malice. She never bought me anything and never gave me pocket money." (Shimada, 2004: 300)

Furthermore, in the letter, she writes that the stepsisters are no different from their mother. They too have bullied and been mean to her, as she explains on one occasion, "One day, Kazue came to visit Umezawa's. She was the queen of complaints: she would pick on anything she disliked and grumble about it all day. On that occasion, she complained that the chair she was sitting on was uneven. Masako said, "Here, put this bit of rag under the leg to make it even." She tossed it to Kazue a sachet that had belonged to my mother. It had been part of her collection." (Shimada, 2004:302)

Tokiko says that no one knows about the treatments towards her from the other members of the Umezawa family, not even their neighbors and classmates because they conceal it very well. In her letter to the detective, she also states:

"All my clothes, toys, and books were hand-me-downs from Tomoko or Akiko. Yukiko and I went to the same primary school. I was one year ahead of her, but being in the same school with her made me feel second-rate." (Shimada, 2004: 300)

Tokiko experiences all of the malicious treatments during her childhood and teenage life that eventually she is haunted by the images of her being unloved and cast away in her own house and by her father. One day she receives help from a kind gentleman who gives her a job at a university hospital and she learns a lot from the job including how to conduct an autopsy. The autopsy performance inspires her and sets a goal in her life. Freudian tripartite deals with traumas and grief in the past which contribute to Tokiko's personality. She begins to think of committing suicide and plans to drink arsenic. After seeing her mother, she decides to change her mind. The parental incompetence shows by her parent, mainly her father. Related to Freud's theory, Tokiko has kept her disappointment inside. Her hate seems to develop in time during her stays with the Umezawa family. Her repressed memories evoke her feelings and force them to the surface. 


\subsection{The Id}

The id is in the unconscious part of our psyche and stores all of the unwanted memories and wrongful desires. At the beginning of the story, there is a letter from Azoth. In the letter, Azoth explains that she has been possessed by the devil. At first, the letter is thought to be written by Heikichi, but by the end of the story detective Mitarai finds out that it is Tokiko who writes it. She says how funny it is for a father and daughter to have similar handwritings and how she uses drawing pencils to blur the writings. Moreover, she is so confident that no one would realize that it is not Heikichi's writings. For those reasons, the first letter which is written by Azoth describes the repressed desires of Tokiko. In Azoth's letter, Tokiko says, "During my childhood, I was possessed. To exorcise the devil in me, I tried everything I could think of" (15). Freud emphasizes that a human's basic instinct is to fulfill his needs and desires (Hossain, 2017). The word "possessed" is the mirror image of Tokiko's traumas of her family's abusive treatment towards her and that she struggles to escape from it. ID is the constant desire that needs to be fed and satisfied immediately due to its impulsive nature. Tokiko continues by stating that, "The devil is relentless, urging me constantly to obey him. To achieve this end, he has created an almighty woman, a Goddess, a Helen of Troy or perhaps a witch" (16). The recent statement from Tokiko in Azoth's letter indicates that "the Devil" is the representation of "the Id", her desire. She implicitly explains that her desire forces her to fulfill what it wants and she could no longer restrain it. The desire has given birth to "an almighty woman". The woman refers to herself who has made up her decision to fight back and to take an act of revenge towards those who have carved pain in her. Further in the letter, she strengthens the Idea by stating, "while being manipulated like a puppet, I dream of the perfect woman. I am mesmerized by her beauty" (17). At this point, her desire has taken over her mind and body, and that she has prepared a plan. In her life, Tokiko has never experienced happiness. She spends her time as a victim of her own family. The more she tries to repress her Id, by trying to commit suicide, as one of the ways, the stronger the desires she experiences. She can no longer ignore the need to fulfill this desire and is ready to feed it. She finally gives herself the satisfaction of the "devil" in her.

\subsection{The Ego and The Super-Ego}

The Ego helps Tokiko to be aware of her surroundings. She realizes that she needs to adapt to the situation and needs to be tough. She plans to commit suicide and meet her mother,

"I look into her eyes, questioning the meaning of life. I could find nothing good about mine, but I realized my mother's situation was even worse. I knew I have to do something good for her before I died." (Shimada, 2004: 302)

In the split seconds of her life at that time, Tokiko's desire controls her and wants her to commit suicide. The Ego has assisted Tokiko in considering her mother's feelings and needs. For once she understands that her mother has also been suffering and she needs to stand up for her. Tokiko acknowledges her surroundings, instead of giving up on her desire. She ignores it and acts like nothing serious has been happening in her mind. She starts planning the murders in detail. Tokiko's act of murdering her father is also another work of the Ego. She is aware that in committing the murders she would need a black sheep to sacrifice. Tokiko thinks her father fits the role, "My father was not the real target; he was just selfish and childish" (303). Tokiko consciously makes a clear decision of whom she has to blame for the murder. The ego moves in the area where it realizes the danger that comes and prepares 
the counter-attack. She needs to stay alive and survive for the moment. The Ego takes her away to stay in her comfort zone and escapes from her responsibility.

Meanwhile, the Super-Ego is the one that urges Tokiko to write two letters. In the first letter, as Azoth, Id appears to be the one who controls her, but the appearance of Super-Ego can also be noticed from the letter by looking at her statement, "I tried to kill them, but I found that I was powerless" (15). The "I" tries to kill "them" and can be assumed that the I is the Super-Ego that tries to stop the Id from making a mistake. Her Super-Ego has been influenced by the Japanese situation at that time where the law states that the punishment for committing murder is a death sentence. The super-Ego is the result of a certain belief, rules, and norms where one lives. Tokiko's Super-Ego works are based on the rules in society. In her second letter, the Super-Ego also shows its existence when she says that, "I have been waiting for you for a long time. That may sound odd, but it is true. I have been suffering from very strong anxiety, which may be the only natural, considering what I have done" (299). The Super-Ego reminds her of what is right and wrong, and her anxiety shows that she realizes that she has made a mistake and it is understandable why she experiences what she feels. In other words, Tokiko has been waiting to be punished, this is where the Super-Ego reminds her. However, when she eventually commits suicide by the end of the story, it proves that her Id still controls her and that she finally escapes from the law that could bind her.

\section{Conclusion}

Tokiko's unconscious psyche has been revealed by using Freudian tripartite of psychoanalysis. Her Id is nonetheless the one that is triggered by the most devastating experiences that she receives from her family. It remains strong until her death since she could finally fulfill her desire and escape from her responsibility. Her Ego has given her the reason to survive and live to pursue an act of well-planned revenge towards her family. But her Ego also has given up to her Id since she finally feeds the "devil" in her. Tokiko's SuperEgo reminds her to keep her responsibility by explaining what truly happens before, during, and after the murders. Tokiko's tripartite builds up her personality into someone who prefers to feed her desire rather than follow what the Super-Ego wants. She remains faithful to herself and ignores the fact that she should be able to accept the consequences of her actions.

\section{References}

Barry, Peter. (2002). Beginning Theory an Introduction To Literary and Cultural Theory. London: University Press.

Blakeney, K. (2010). Perceptions of Heroes and Villains in European Literature. Inquiries Journal/Student Pulse, 2(01). Retrieved from http://www.inquiriesjournal.com/ a? Id $=119$

Downing, Angela. (2009). Surely as a Marker of Dominance and Entitlement in the Crime Fiction of P.D. James, Bruno Studies in English, 35(2), pp. 79-92. https://digilib.phil.muni.cz/handle/11222.digilib/105147.

Giordano, Giuseppe. (2020). The Contribution of Freud's Theories to the Literary Analysis of Two Victorian Novels: Wuthering Heights and Jane Eyre. International Journal of English and Literature, 11(2), pp. 29-34. https://academicjournals.org/journal/IJEL/ article-abstract/472AEFC63846. 
Hossain, Mahroof. (2017). Psychoanalytic Theory used in English Literature: A Descriptive Study, Global Journal of Human Social Science: Linguistics \& Education, 17(1), pp. 4046. https://globaljournals.org/GJHSS_Volume17/3-Psychoanalytic-Theory-used.pdf.

Mario, Giovanny., et al. (2013). A Psychoanalysis and Biographical Analysis of the Main Character as Well as the Author of Sherlock Holmes: A Study in Scarlet by Sir Arthur Conan Doyle. Retrieved on 10 October 2020 from http://library.binus.ac.ld/ Collections/ethesis_det.

Onwuegbuzie, Anthony J., et al. (2012). Qualitative Analysis Technique for the Review of the Literature. The Qualitative Report, 17(1), pp. 1-3. https://nsuworks.nova.edu/ tqr/vol17/iss28/2/.

Pope, Rob. (2002). The English Studies Book An Introduction to Language, Literature, and Culture. London: Routledge.

Sarijaloo, Shadi Torabi., \& Kiaei, Shahram. (2015). A Freudian Reading of Samuel Richardson's Pamela. International Journal of Applied Linguistics \& English Literature, 5(2), pp. 30-39. https://www.journals.aiac.org.au/index.php/IJALEL/ article/view/2130.

Shimada, Soji. (2004). The Tokyo Zodiak Murders. London: Pushkin Vertigo.

Shpayer-Makov, Haia. (2011). Revisiting the Detective Figure in Late Victorian and Edwardian Fiction: A View from the Perspective of Police History, Law, Crime, and History. Law crime and History, 1(2), pp. 165-193. https//pearl.plymouth.ac.uk/handle/ $10026.1 / 8867$.

Zhu, Jiang., \& Bao, Yuxiao. (2012). Analysis of the Character of Clyde in An American Tragedy by Tripartite Personality Structure Theory, Theory, and Practice in Language Studies, 2(12), pp. 2556-2560. http://www.academypublication.com/issues/past/tpls/vol 02/12/14.pdf. 